\title{
The Effect of Finger Hold and Music Therapy to Insomnia in Elderly
}

\author{
Annisa Nur Septiyana ${ }^{1}$, Sigit Priyanto $^{2}$, Priyo $^{3}$, Suryo Ediyono ${ }^{4}$ \\ \{masigit_fikes@yahoo.com ${ }^{2}$ \} \\ Faculty Health Science, Universitas Muhammadiyah Magelang 1,2,4 \\ Faculty of Cultural Sciences (FIB), Universitas Sebelas Maret Surakarta, Indonesia ${ }^{3}$
}

\begin{abstract}
Insomnia is one of the complaints felt by the elders. In Indonesia, prevalence rate of insomnia in Indonesia is around 67 percent. Insomnia increases in women up to 40 percent at the age of fourty-fifty years old. The one of pharmacological therapy for insomnia is given finger hold and music therapy. Finger hold therapy will stimulate the release of the hormone melatonin and music will produce $\beta$ endorphin and encephalin substances, both of which can make the body relax, calm, reduce pain and cause feelings of pleasure. The purpose of the study to know the effect of finger hold and music therapy to insomnia in elderly at Ngadiharjo Village Borobudur District, Magelang Regency. The research method used is quays experiment with two group pre and post with control group. The sample used was 46 people and separted to the group there is 23 people. Sample technique used was proportional random sampling. The differences in insomnia level after finger hold and music therapy in intervention group and control group is $<0,05$ with $p$ value 0,000 . There is an influence of finger hold and music therapy on the level of insomnia in the elderly in Ngadiharjo Village, Borobudur District, Magelang Regency in 2019. Such therapy can be used as alternative therapy or complementary therapy to overcome insomnia the elderly.
\end{abstract}

Keywords: Insomnia, finger hold, music therapy, elderly

\section{Introduction}

Every human being will experience increasing age which is a physiological process, in the process of aging a person will experience physical, mental and socio-economic problems. One of the problems that occur in the elderly is sleep disorders or what is often called insomnia. About $50 \%$, experienced insomnia by age 65 years or older. In Indonesia, the decrease in sleep effectiveness experienced by the elderly at night is $70 \%$ to $80 \%$ compared to young people. The percentage of people with insomnia is higher in the elderly, where 1 in 4 at the age of 60 years or older experiences very serious insomnia.

Increasing age does not change the total amount of sleep, but in the elderly the quality of sleep changes. Adults and seniors spend an average of 6.5 to 7.5 hours of sleep over a 24-hour period. However, every year the prevalence of sleep disorders increases with age and the aging process. Kaplan and Sadock reported that approximately $40-50 \%$ of the elderly population suffer from sleep disorders. In the elderly, changes in the hormone melatonin (which regulates sleep and rest rhythms) are found so that the elderly experience sleep disturbances [1]. Sleep disturbances can occur in all levels of age, but it is more often a complaint among the elderly. 
Insomnia in the elderly is caused by lack of physical activity throughout the day, sleeping intermittently throughout the day, anxiety and depression, uncomfortable room atmosphere, frequent urination at night and urinary tract infections [4].

The impact of insomnia is physical health losses such as heart problems, diabetes, weak antibodies, and chronic fatigue, psychological losses and financial losses. Physiologically, poor sleep quality is associated with decreased memory and concentration such as disorientation, forgetfulness, confusion and impaired performance in psychomotor tests. Sleep disturbances are also associated with an increased risk of falls, cognitive decline, and higher death rates. Insomnia, if underestimated, is tantamount to letting the body weaken gradually, which can cause serious health problems and reduce the quality of life of the elderly [7].

Based on a preliminary study conducted by researchers in Ngadiharjo Village, Borobudur District, on 10 elderly people, there were 7 elderlies who said they could not sleep at night due to stress and unhealthy lifestyles, so that the elderly felt unfocused and disturbed their activities during the day. Of 7 elderlies, 2 elderly experienced mild insomnia (28.6\%), 4 elderly experienced moderate insomnia $(57.1 \%)$ and 1 elderly experienced severe insomnia (14.3\%). To stimulate sleep, the elderly had previously made efforts by praying and dhikr before going to sleep, some did not make any efforts. They think that insomnia is not a problem that should be handled, even though insomnia will be bad for the long term. When interviewed, they said they liked Javanese music in the keroncong genre and often heard Javanese music at home while resting, the elderly also said they felt comfortable and relaxed and the Javanese music made them feel sleepy when listening to them.

Finger grip relaxation against insomnia can be combined with music therapy so that it is expected to have a maximum effect in helping the elderly comfort. Music can touch individuals both physically, psychosocial, emotionally and spiritually. Musical vibrations that are closely tied to the basic body frequencies or vibration patterns have a very powerful healing effect on the human body, mind and soul [4].

\section{Method}

The research design used in this study was a Quays Experiment with Two Group pre-test and post-test with a control group design, which consisted of an intervention group and a control group who were given different interventions and then the results of the 2 groups were compared. In this study, the first group was given a combination of finger grip therapy and music therapy intervention by measuring before and after the intervention. the second group was not given treatment and was used as a control group. To be able to find out whether there is an effect of giving a combination of finger grip therapy and music therapy in the intervention group, the results after treatment (post-test) are then compared with the control group (pre-test).

The sampling technique in this research is proportional random sampling, which is simple random sampling and the technique is divided into two ways by drawing or also by using a table of numbers or random numbers. The population was 1280 elderly people over 60 years of age in Ngadiharjo Borobudur Village, while the study sample consisted of 23 respondents for each intervention group and control group, so that the total number of respondents was 46 respondents. 


\section{Results and Discussion}

\subsection{The Effect of Finger Grip Therapy and Music on Insomnia Levels Before and After Action in the Intervention Group}

The differences in insomnia level after finger hold and music therapy in intervention group and control group is $<0,05$ with $p$ value 0,000 . Based on table 1 shows that there are 23 respondents who experienced a decrease in the level of insomnia before and after being given finger grip therapy and music.

Table 1. Insomnia Level

\begin{tabular}{lllll}
\hline Insomnia level & Mean & Mean Different & Sd & p value \\
\hline Before & 27,91 & 3,75 & 4,889 & 0.000 \\
After & 24,17 & & 4,217 &
\end{tabular}

*Uji Wilcoxon, 2020

The average result of the insomnia level before being given finger grip therapy and music was 27.91 with a standard deviation of 4.889 and after being given finger grip therapy and music, the average insomnia level was 24.17 with a standard deviation of 4.217 . The difference between before and after being given finger grip therapy and music was 3.75 with $p=0.000$ and $\mathrm{Z}$ count of 4.235 . This means that the $\mathrm{p}$ value $<0.05$ and $\mathrm{Z}$ count $>\mathrm{Z}$ which indicates that there is a significant decrease between before and after being given finger grip therapy and music. From this table, it is known that there is an effect of finger grip therapy and music to reduce the respondents' insomnia level.

The research conducted by these researchers used finger handheld therapy and music because finger handheld therapy can stimulate the release of the hormone melatonin which stimulates sleep and listening to music can produce $\beta$ endorphins and enkephalin which are sleep neurotransmitters. This is supported by research by Pinandita [6] which states that the human body produces energy, this energy flows through the meridian system that connects various organs of the body. Meredian energy in the hand provides reflex stimulation when grasped, this stimulation will send a kind of shock or electricity to the brain. These waves are received by the brain and processed quickly and then forwarded to the nerves in the affected organs, so that the blockages in the energy pathway become smooth [6]. Physiologically, this stimulation will trigger the release of the hormone melatonin which plays an important role in the regulation of biological functions that regulate sleep and rest rhythm so that insomnia can decrease [1]. Meanwhile, Natalina's research [5] states that Javanese music therapy can produce $\beta$ endorphins and enkephalin, which are sleep neurotransmitters. able to make the body relax, reduce pain and cause feelings of pleasure so that the elderly can fall asleep more easily.

The measurement of insomnia levels before and after the intervention was carried out using the IRS (Insomnia Rating Scale) questionnaire. Researchers chose to use the IRS because it has been standardized by the KSPBJ (Jakarta Biological Psychiatry Study Group). IRS is used to measure insomnia starting from problems with sleep entry disturbances, sleep duration, sleep quality and quality after waking up. In a study conducted by Erlina using the KSBPJ-IRS questionnaire, the validity results were 0.89 and 0.83 reliability was carried out by 30 elderly people at the Wedha Cipray Bandung Home, then developed by Buysse [3] to measure sleep quality in several categories consisting of no insomnia, mild insomnia, moderate insomnia and severe insomnia. 


\subsection{Effect of finger grip therapy and music on insomnia levels before and after action in the control group}

Based on Table 2, the differences in insomnia level after finger hold and music therapy in intervention group and control group is $>0,05$ with $p$ value 0,102 . The decrease in insomnia levels may occur if respondents understand and apply the information provided by researchers to reduce insomnia.

Table 2. Insomnia level after finger hold and music therapy

\begin{tabular}{lllll}
\hline Insomnia level & Mean & Mean Different & Sd & p value \\
\hline Pre intervention & 27,74 & 0,2 & 5,110 & 0,102 \\
Post intervention & 27,52 & & 5,026 & \\
\hline
\end{tabular}

*Uji Wilcoxon, 2020

Providing education and information related to insomnia can increase knowledge so that there is awareness to take action and control the influencing factors so as to reduce insomnia and improve the degree of health. This is supported by Notoatmojo that health promotion is not only attempted to facilitate changes in therapeutic behavior, health promotion is also a process of community awareness or giving and increasing public knowledge about health.

The results of this study are in line with the research conducted by Sri Aditayi (2010) in the control group, it is known that the difference in the mean value of post-test insomnia is 11.67. The results of statistical tests using the paired t-test sample test obtained a t value of 0.535 with a probability value of Sig (tailed) of 0.601 which is greater than 0.05 , which means that there is no significant difference in the degree of insomnia between the pre-test and post-test. The mean degree of insomnia in the control group also decreased, although the decrease was not significant, because the elderly in this group underwent activities programmed by the PTSW Budi Luhur unit. These activities, such as skills, arts, and gymnastics for the elderly, are relaxation activities that can reduce tension and anxiety in the elderly.

\subsection{Effect of finger grip therapy and music before and after action on the intervention group and control group}

Based on Table 3, experienced a decrease in the average level of insomnia before and after given action, in the intervention group 19.41, while in the control group 27.59, the difference before and after treatment was 8.18 with $\mathrm{p}$ value $=0.038$ and $\mathrm{Z}$ count of -2.071 .

Table 3. Effect of finger grip therapy and music

\begin{tabular}{lccll}
\hline Intervention & Mean & Mean Different & Z & p value \\
\hline Intervention group & 19,41 & 8,18 & -2.071 & 0.038 \\
Control group & 27,59 & & & \\
\hline
\end{tabular}

This means that the $\mathrm{p}$ value $<0.05$ and $\mathrm{Z}$ count $>\mathrm{Z}$ which indicates that there is a significant difference between giving finger grip therapy and music and those not given finger grip therapy and music on the level of insomnia in respondents. From the table above, it can be seen that there is a significant effect between finger grip therapy and music to reduce the level of insomnia among respondents $(\mathrm{p}$ value $=0.038)$. 
The problem that usually occurs in the elderly is sleep disturbance / insomnia. Insomnia is a condition in which a person has difficulty starting to sleep, maintaining sleep and waking up too early [7]. Research shows that people who get sleep deprived easily remembering information, but the difficulty in conveying or using the information is due to the physical condition, especially mental decline due to lack of rest. The causes of insomnia in the elderly consist of several factors such as increased drug consumption, death of a spouse or close friend, retirement and social patterns. Insomnia in the elderly is caused by anxiety about the negative feelings they experience [7]. Insomnia in the elderly is caused by lack of physical activity throughout the day, sleep intermittently throughout the day, anxiety and depression, uncomfortable room atmosphere, frequent urination at night and urinary tract infections [4].

The impact of insomnia, namely an increase in the risk of falling, cognitive decline, and a higher mortality rate. Insomnia if underestimated is the same as letting the body weaken gradually, so that it can cause serious health problems and reduce the quality of life of the elderly [7]. The long-term impact of insomnia is to increase the risk of death and even depression. Giving finger and music handheld therapy is by preparing music before doing finger grip therapy. The music used is Javanese keroncong style music with soft rhythm and slow tempo. Keroncong music therapy is given for 10 minutes before going to bed for 8 times at night. When given music therapy, respondents are encouraged to grasp the fingers for a duration of 2 minutes per finger [2]. In this study, researchers only taught therapy during the day and advised respondents to repeat it at night before going to bed.

Hand-held finger therapy and music can stimulate the release of the hormone melatonin which stimulates sleep and listening to music can produce, endorphins and encephalin which are sleep neurotransmitters. This is supported by research by Pinandita [6], which states that the human body produces energy, this energy flows through the meridian system that connects various organs of the body. Meredian energy in the hand provides reflex stimulation when grasped, this stimulation will send a kind of shock or electricity to the brain. These waves are received by the brain and processed quickly and then forwarded to the nerves in the affected organ, so that the blockage in the energy pathway becomes smooth [6]. Physiologically, this stimulation will trigger the release of the hormone melatonin which plays an important role in the regulation of biological functions that regulate sleep and rest rhythm so that insomnia can decrease [1]. Whereas in Natalina's research [5], Javanese music therapy can produce $\beta$ endorphin and encephalin substances which are sleep neurotransmitters, able to relax the body, reduce pain and cause feelings of pleasure so that the elderly can fall asleep more easily. Javanese music can be used as a therapy with a cultural approach [8]. The cultural approach through the application of Javanese style music is a development of philosophy as a reference for a science. Insomnia level graph showed on Figure 1.

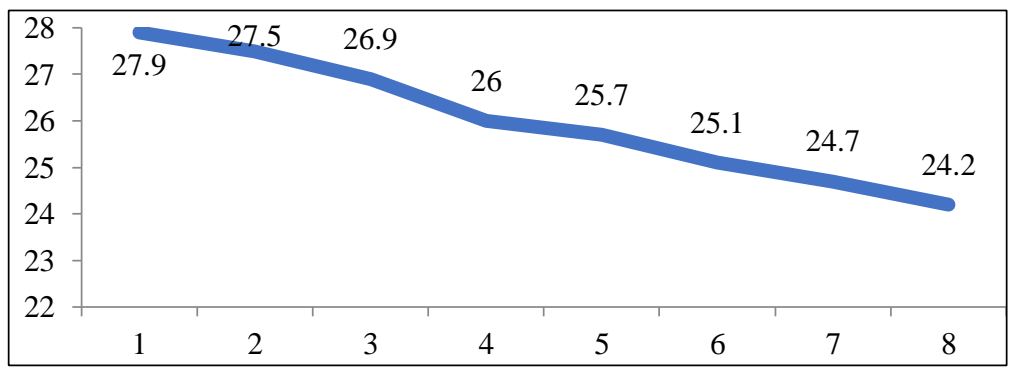

Fig. 1. Insomnia level graph 
Based on the Figure 1, it can be concluded that after intervention for 8 consecutive days there was a significant decrease on the third and sixth day with an average decrease of 0.525 .

\section{Conclusion}

There is an effect of reducing the level of insomnia, before and after finger grip therapy and Javanese music with a significance level of 0.000. There was a significant difference in the reduction in the level of insomnia, between the intervention group and the control group after finger grip therapy and Javanese music, with a significance level of 0.038. Javanese music can be used as a therapy by applying a cultural approach

\section{References}

[1] Adiyati, S. 2010. Pengaruh Aromatherapi Terhadap Insomnia Pada Lansia di PTSW Unit Budi Luhur Kasong Bantul. Skripsi. Yogyakarta: Universitas Negri Yogyakarta

[2] Apriliani. M, Mansyur. A, Rifdah. A. 2020. Efektifitas Mendengarkan Murotal Al - Qur'an Dalam Menurunkan Tingkat Insomnia Pada Mahasiswa. Jurnal Psikologi Islami Vol 5. No. 2 Desember 2020:146-154

[3] Buysse, Daniel J. 2010. Insomnia: The Jurnal of Lifelong Learning in Psychiatry. Vol.3, No.4

[4] Maryam, dkk. 2013. Mengenal Usia Lanjut dan Perawatanya. Jakarta: Salemba Medika

[5] Natalina. 2013. Terapi Musik (Bidang Keperawatan). Jakarta: Mitra Wacana Media

[6] Pinandita, I. Purwanti, E. \& Utoyo, B. (2012), Jurusan Keperawatan STIKes Muhammadiyah Gombong Pengaruh Teknik Relaksasi Genggam Jari Terhadap Penurunan Intensitas Nyeri Pada Pasien Post Operasi Laparatomi, Jurnal Ilmiyah Kesehatan Keperawatan, 8 (1).

[7] Puspitosari. 2011. Gangguan Pola Tidur Pada Kelompok Usia Lanjut, Journal Kedokteran Trisakti, Vol 21, No 1

[8] Ediyono Suryo, 2015 Filsafat Ilmu, Surakarta, Penerbit Kaliwangi 